\title{
Rancangan Sistem Informasi Pengajuan dan Pelaporan Tunjangan Kinerja Kementerian Keuangan Menggunakan Metode Prototype
}

\author{
Akhmad Syarifudin $^{[1]}$, Nur Ani ${ }^{[2]}$ \\ Program Studi Sistem Informasi ${ }^{[1], ~[2] ~}$ \\ Universitas Mercu Buana \\ Jakarta Barat, DKI Jakarta \\ 41815110083@student.mercubuana.ac.id ${ }^{[1]}$, nur.ani@mercubuana.ac.id ${ }^{[2]}$
}

\begin{abstract}
Abstrak- Sistem Informasi Pengajuan dan Pelaporan Tunjangan Kinerja merupakan sistem yang dirancang untuk membantu Biro Perencanaan dan Keuangan Kementerian Keuangan dalam mengelola tunjangan kinerja. Proses pengajuan dan pelaporan pembayaran tunjangan kinerja selama ini masih menggunakan cara manual sehingga membutuhkan waktu yang cukup lama dari satker sampai ke kementerian. Metode yang digunakan dalam pengembangan sistem adalah prototyping. Selain mempermudah proses pengajuan dan pelaporan tunjangan kinerja, aplikasi juga dirancang agar kementerian dapat memonitor progres pengajuan dan pelaporan pada berbagai tingkatan baik unit eselon I, kanwil maupun satker.
\end{abstract}

Kata kunci : tunjangan kinerja; monitoring; prototype

\section{PENDAHULUAN}

Pemanfaatan teknologi informasi (TI) dalam pemerintahan telah banyak dilakukan untuk monitoring dan pencatatan, antara lain monitoring pengadaan barang dan jasa [1], [2], monitoring inventori barang [3], dan monitoring satuan kerja (satker) [4]. Pemanfaatan TI telah terbukti meningkatkan keterandalan dan ketepatwaktuan laporan keuangan pemerintah daerah Kab. Pesisir Selatan [5].

Kementerian Keuangan adalah instansi pemerintah yang memiliki kantor vertikal/satuan kerja (satker) yang tersebar di seluruh wilayah Indonesia. Dalam proses pembayaran tunjangan kinerja, setiap satker harus mengajukan permintaan kebutuhan dana secara berjenjang melalui kantor wilayah (kanwil) dan unit eselon I (UE 1) kepada Sekreteriat Jenderal (Biro Perencanaan dan Keuangan). Demikian juga setelah tunjangan kinerja dibayarkan, satker harus mengirimkan laporan pertanggungjawaban secara berjenjang. Hal ini berbeda dengan pembayaran gaji yang dibayarkan langsung oleh masing-masing satker kepada pegawai. Proses pengajuan dan pelaporan pembayaran tunjangan kinerja ini dilakukan secara semi manual.

Permasalahan yang sering terjadi adalah kesalahan input data karena adanya redundansi penginputan data oleh satker, kanwil, unit eselon I dan Biro Perencanaan dan Keuangan. Proses rekapitulasi yang dilakukan berjenjang juga rawan terjadi kesalahan baik dikarenakan kesalahan input, kesalahan penulisan formula Excel, atau hide row/column file Excel pada data yang tidak diperlukan namun masih terhitung dalam formula. Selain itu, keterlambatan pengajuan pembayaran maupun penyampaian laporan pertanggungjawaban juga menjadi keluhan pegawai Biro Perencanaan dan Keuangan. Permasalahan lainnya adalah informasi penyetoran pajak tidak sampai kepada Biro Perencanaan dan Keuangan karena hanya tercantum dalam laporan per satker dan tidak tercantum dalam laporan tingkat Kementerian. Data penyetoran pajak merupakan salah satu data yang menjadi objek pemeriksaan auditor (BPK), sehingga ketika diperlukan, Biro Perencanaan dan Keuangan harus mengumpulkannya secara berjenjang dari satker.

Berdasarkan latar belakang tersebut, maka masalah yang akan diteliti dapat dirumuskan tentang bagaimana merancang aplikasi untuk dapat mencatat pengajuan pembayaran (permintaan dana) dan pelaporan tunjangan kinerja yang dilakukan oleh satker, memonitor permintaan dana dan pelaporan tunjangan kinerja satker, dan sekaligus memperoleh informasi penyetoran pajak ( $\mathrm{PPh}$ Pasal 21 atas Tunjangan Kinerja) yang disetorkan oleh satker.

Sedangkan batasan masalah dalam penelitian ini adalah ruang lingkup peneitian terbatas pada Biro Perencanaan dan Keuangan Kementerian Keuangan sebagai penanggung jawab pengelolaan dana tunjangan kinerja, tidak sampai ke level di bawahnya yaitu unit eselon I, kanwil, maupun satker. Selain itu detil pencatatan data adalah per satker bukan per pegawai, dan aplikasi dirancang untuk tidak terhubung dengan sistem pembayaran lain yang sudah ada.

\section{METODE PENELITIAN}

A. Metode Pengumpulan Data

1. Observasi

Pengamatan langsung dilakukan dengan melihat proses kerja pengelolaan tunjangan kinerja pada Biro Perencanaan dan Keuangan

2. Wawancara

Wawancara dilakukan terhadap pegawai Biro Perencanaan

ISSN : 2301-7988

E-ISSN : 2581-0588

DOI : $10.32736 /$ sisfokom.v8i2.641 
dan Keuangan yang menangani pengelolaan tunjangan kinerja yaitu pada Subbagian Pengelolaan Tunjangan Kinerja

3. Studi Pustaka

Studi pustaka dilakukan dengan mengumpulkan teori-teori yang berhubungan dengan penelitian dari berbagai literatur baik berupa buku maupun jurnal. Selain itu juga dengan mempelajari dokumen-dokumen terkait tunjangan kinerja Kementerian Keuangan, terutama peraturan perundangundangan yang melandasinya.

\section{B. Metode Pengembangan Sistem}

Metode yang digunakan dalam pengambangan sistem adalah prototyping. Model ini menghasilkan prototype dari suatu perangkat lunak yang dapat digunakan sebagai perantara pengembang dengan pengguna untuk berinteraksi dalam pengembangan sistem informasi. Prototype adalah sebuah versi awal dari perangkat lunak yang digunakan untuk mendemonstrasikan konsep, mencoba berbagai pilihan desain, dan menggali lebih banyak permasalahan dan solusinya [6]. Beberapa manfaat prototyping adalah [7]:

- Mewujudkan sistem sesungguhnya dalam sebuah replika sistem yang akan berjalan, menampung masukan dari pengguna untuk kesempurnaan sistem.

- Pengguna akan lebih siap menerima setiap perubahan sistem yang berkembang sesuai dengan berjalannya prototipe sampai dengan hasil akhir sistem yang dikembangkan.

- Prototype dapat ditambah maupun dikurangi ketika proses pengembangan sedang berjalan. Kemajuan tahap demi tahap dapat diikuti langsung oleh pengguna.

- Penghematan sumber daya dan waktu dalam menghasilkan produk yang lebih baik dan tepat guna bagi pengguna.

Tahapan-tahapan dalam pengembangan model prototype adalah [7], [8]:

\section{Komunikasi}

Pada tahap ini, dilakukan identifikasi masalah dan kebutuhan sistem melalui komunikasi yang intensif dengan pengguna.

\section{Perencanaan secara cepat}

Perencanaan secara cepat berfokus pada representasi semua aspek perangkat lunak yang terlihat oleh pengguna akhir seperti rancangan antarmuka pengguna dalam bentuk Mock Up atau desain tampilan

\section{Pemodelan perancangan secara cepat}

Pemodelan menggunakan UML Diagram seperti Use Case Diagram, Activity Diagram, Sequence Diagram, dan Class Diagram

\section{Pembentukan prototype}

Pada tahap ini dibuat prototype yang mewakili sistem yang akan dibangun.

5. Penyerahan sistem ke pelanggan, pengiriman dan umpan

\section{balik}

Pada tahap ini dilakukan evaluasi terhadap prototype yang telah dibangun dengan pengguna.

\section{PEMBAHASAN}

\section{A. Analisis Sistem Berjalan}

\section{Analisis Proses Bisnis}

Periode pembayaran tunjangan kinerja bagi pegawai Kementerian Keuangan berdasarkan Peraturan Presiden Nomor 156 Tahun 2014 adalah setiap bulan. Sesuai dengan PMK 273/2014 [9], periode ini disebut dengan pembayaran rutin/bulanan. Selain periode rutin/bulanan ini, terdapat beberapa jenis periode pembayaran yang sifatnya tidak rutin. Jenis periode pembayaran tunjangan kinerja di Kementerian Keuangan dapat dikelompokkan sebagai berikut:

- Rutin yaitu setiap bulan.

- Rapel

Umumnya pembayaran rapel pegawai dilakukan bersamaan dengan pembayaran rutin jika sifatnya individual, misalnya karena kenaikan kelas jabatan pegawai. Namun demikian dalam kondisi tertentu pembayaran rapel dapat dilakukan terpisah dari pembayaran rutin sesuai kebijakan.

- THR

Kebijakan pembayaran tunjangan kinerja sebagai salah satu komponen penghasilan THR pernah dilaksanakan tahun 2018 dengan terbitnya Peraturan Pemerintah Nomor 19 Tahun 2018. Periode ini belum tentu tiap tahun ada karena tergantung kebijakan pemerintah/presiden.

- Ke-13

Sebagaimana THR, periode pembayaran tunjangan kinerja ke-13 juga berdasarkan kebijakan. Untuk melaksanakannya diperlukan peraturan tersendiri yaitu Peraturan Pemerintah.

Pada setiap periode pembayaran terdapat tahapan-tahapan yang terdiri dari permintaan dana, droping dana, pembayaran tunjangan kinerja, dan pelaporan yang dapat diilustrasikan pada gambar berikut:
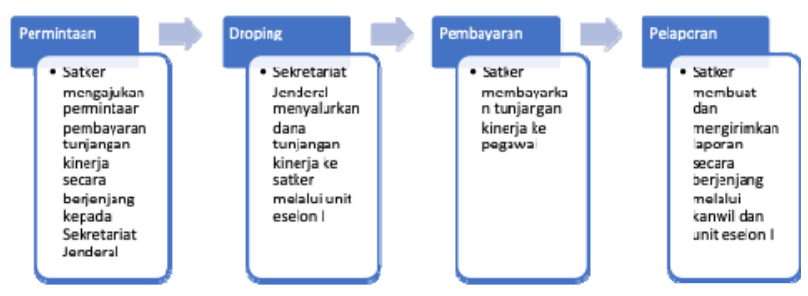

Gambar 1. Tahapan-tahapan dalam setiap periode pembayaran

Proses pengajuan permintaan dan pelaporan pembayaran tunjangan kinerja dilakukan secara berjenjang dari satker kepada Sekretariat Jenderal Kementerian Keuangan melalui kanwil dan unit eselon I.

ISSN $\quad: 2301-7988$

E-ISSN : 2581-0588

DOI $\quad: 10.32736 /$ sisfokom.v8i2.641 


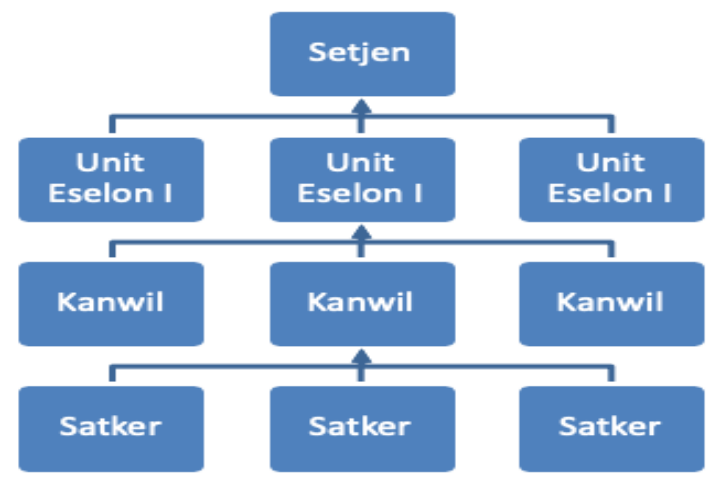

Gambar 2. Proses Permintaan dan Pelaporan Pembayaran Tunjangan Kinerja

\section{Identifikasi Masalah}

Untuk mengidentifikasi masalah dari sistem berjalan, digunakan analisis PIECES [10]. PIECES framework adalah kerangka yang dipakai untuk mengklasifikasikan suatu problem, opportunities, dan directives yang terdapat pada bagian scope definition analisis dan perancangan sistem [11].

- Performance

Proses pengajuan permintaan pembayaran dan pelaporan tunjangan kinerja yang ada saat ini membutuhkan waktu yang lama. Data dikirimkan dalam bentuk dokumen fisik. Untuk mempercepat proses rekapitulasi di tingkat kanwil dan unit eselon I biasanya data softcopy dikirimkan melalui email dalam format MS Excel. Untuk mendapatkan informasi kebutuhan dana tunjangan kinerja dalam satu periode pembayaran, Sekretariat Jenderal (Biro Perencanaan dan Keuangan) harus menunggu semua unit eselon I selesai merekap data.

- Information

o Outputs

- Informasi yang ada dalam dokumen permintaan dana tunjangan kinerja tingkat unit eselon I yang diterima oleh Biro Perencanaan dan Keuangan hanya memuat saldo awal dan kebutuhan dana per satker. Sedangkan di dalam kebutuhan dana tersebut terdapat informasi mengenai jumlah tunjangan kinerja yang dibayarkan kepada pegawai dan jumlah pajak (PPh Pasal 21) atas tunjangan tersebut.

- Dalam dokumen laporan pertanggungjawaban tingkat unit eselon I yang dikirimkan kepada Biro Perencanaan dan Keuangan telah terdapat informasi mengenai jumlah pajak yang disetorkan, namun informasi Nomor Transaksi Penerimaan Negara (NTPN) belum tersedia. Kalaupun ada, data NTPN tidak lengkap, terutama untuk satker yang dalam satu periode pembayaran menyetorkan pajak lebih dari satu kali.

o Inputs

Data NTPN pada satker yang melakukan penyetoran pajak lebih dari satu kali dalam satu periode pembayaran tidak tercatat dalam laporan.

\section{o Stored Data}

Data disimpan dalam file-file yang terpisah pada masing-masing satker, kanwil dan unit eselon I dan tidak terorganisir dengan baik. Kemudahan proses pencarian data tergantung dari bagaimana pegawai yang bertugas menangani pembayaran tunjangan kinerja mengorganisir file-file tersebut. Selain itu, petugas tersebut sering berganti karena dimutasi.

\section{- Economics}

Proses rekapitulasi pada tingkat kanwil, unit eselon I dan kementerian memerlukan penginputan ulang data yang sering terjadi kesalahan. Kesalahan yang terjadi karena data yang sama diinput berulang pada ini setidaknya dapat menimbulkan dua dampak yaitu penurunan produktivitas pegawai dan pemborosan ATK. Dokumen yang sudah dicetak dengan data yang salah harus dicetak ulang dengan data yang benar, dan jika sudah dikirimkan ke unit organisasi di atasnya maka harus dikirimkan ulang revisi dokumennya.

- Control

Sistem berjalan tidak memungkinkan untuk selalu dapat dilakukan validasi pada saat input data. Kesalahan perhitungan sangat mungkin untuk terjadi, misalnya kesalahan rumus yang dibuat oleh pegawai pada file MS Excel. Kesalahan penulisan rumus dapat terjadi karena proses copy-paste yang kurang cermat atau kesalahan penunjukan referensi cell pada MS Excel. File yang disimpan dalam komputer yang dipakai secara bersamasama juga meningkatkan kemungkinan data diakses oleh orang yang tidak berkepentingan.

- Efficiency

Adanya redundansi penginputan data pada tingkat kanwil dan unit eselon I. Dimana data yang sudah diinput oleh satker diinput lagi oleh kanwil dan unit eselon I. Redundansi ini selain tidak efisien juga sering terjadi kesalahan yang menyebabkan adanya revisi laporan kanwil dan unit eselon I. Revisi laporan ini juga merupakan inefisiensi.

- Service

Kesalahan yang terjadi akibat redundansi juga mengakibatkan data/laporan yang diterima oleh Biro Perencanaan dan Keuangan menjadi kurang akurat. Proses semi manual tidak mudah digunakan karena pada saat merekap data harus menginput ulang data yang sudah ada dan menghitung secara manual. Meskipun proses perhitungan dapat dilakukan dengan formula pada Excel namun harus melakukan pengecekan ulang untuk memastikan formula yang ditulis sudah benar.

\section{B. Analisis Kebutuhan}

Analisis kebutuhan dilakukan dengan cara menentukan user requirement definition yang memuat kebutuhan sistem dari perspektif pengguna secara umum. User requirement definition ini kemudian akan dirinci lebih detil ke dalam system requirement specification [6].

\section{User Requirement Definition}

Secara umum, fungsi-fungsi utama dari sistem informasi 
pengajuan dan pelaporan pembayaran tunjangan kinerja Kementerian Keuangan meliputi:

- Admin dapat mengelola periode pembayaran

- Satker dapat mengelola permintaan

- Kanwil/unit eselon I dapat melakukan verifikasi (setujui/tolak) permintaan dan laporan

- Admin, kanwil dan unit eselon I dapat memonitor permintaan dan laporan

- Unit eselon I dapat mengelola data droping

- Satker dapat mengelola laporan

\section{System Requirement Spesification}

- Pengelolaan periode pembayaran oleh admin (Biro Perencanaan dan Keuangan):

o Di dalam sistem hanya ada satu periode pembayaran yang aktif (sedang berjalan).

o Sistem menyediakan fungsi untuk menambah periode pembayaran jika periode sebelumnya telah selesai.

o Sistem menyediakan fungsi untuk menutup/menyelesaikan periode pembayaran yang sedang berjalan.

o Periode pembayaran dapat diubah hanya jika periode tersebut sedang berjalan, periode yang sudah selesai tidak dapat diubah lagi.

o Dalam satu bulan, tidak boleh lebih dari satu periode pembayaran rutin.

o Informasi yang terdapat dalam periode pembayaran harus memuat tahun dan bulan pembayaran, jenis pembayaran (rutin, rapel dsb), deskripsi/judul, dan periode pembayaran sebelumnya (untuk mendapatkan informasi saldo awal periode saat ini dari saldo akhir periode sebelumnya).

- Pengelolaan permintaan oleh satker:

o Satker dapat menambah, mengubah dan menghapus rincian kebutuhan hanya pada periode pembayaran yang sedang berjalan.

o Rincian kebutuhan memuat informasi jenis pembayaran, tunjangan kinerja yang harus dibayarkan kepada pegawai, dan tunjangan $\mathrm{PPh}$. Jumlah kebutuhan adalah tunjangan kinerja yang harus dibayar ditambah tunjangan $\mathrm{PPh}$.

o Sistem menyediakan fungsi untuk menghitung permintaan satker yang diperoleh dari total kebutuhan dikurangi saldo awal.

o Setelah selesai menghitung permintaan satker dapat mengirimkan permintaan.

o Data permintaan tidak dapat diubah lagi setelah dikirimkan.

- Verifikasi permintaan dan laporan oleh kanwil dan unit eselon I:

o Setelah permintaan/laporan dikirmkan oleh satker, kanwil dapat menyetujui atau menolak permintaan/laporan.

o Kanwil dapat mengirimkan permintaan/laporan setelah semua permintaan/laporan satker di bawahnya disetujui.

o Setelah permintaan/laporan dikirimkan oleh kanwil, unit eselon I dapat menyetujui atau menolak permintaan/laporan.

o Unit eselon I dapat mengirimkan permintaan/laporan setelah semua permintaan/laporan kanwil di bawahnya disetujui.

o Satker dapat mengubah data permintaan/laporan dan mengirimkan kembali setelah ditolak oleh kanwil/unit eselon I.

- Monitoring permintaan dan laporan:

o Admin dapat melihat data permintaan/laporan pada level unit eselon I, kanwil, dan satker sampai rincian kebutuhan, pembayaran, dan penyetoran pajak dan saldo akhir.

o Unit eselon I dapat melihat data pada level kanwil dan satker di bawahnya.

o Kanwil dapat melihat data satker di bawahnya.

o Sistem menyediakan fungsi bagi admin, unit eselon I dan kanwil untuk melihat status perkembangan data satker. Status data tersebut antara lain draft permintaan/laporan, permintaan/laporan dikirim ke kanwil/unit eselon I/admin, permintaan/laporan ditolak/disetujui kanwil/unit eselon I.

o Admin, unit eselon I dan kanwil dapat melihat data pembayaran berdasarkan jenis pembayaran.

o Admin, unit eselon I dan kanwil dapat melihat data setoran pajak dan mengunduh dalam format MS Excel.

- Pengelolaan data droping oleh unit eselon I

o Setelah admin menerima pengajuan permintaan, unit eselon I dapat mengisi data droping dana tunjangan kinerja yang ditransfer ke satker-satker di bawahnya.

o Sistem menyediakan fungsi bagi unit eselon I untuk mengisi data droping semua satker di bawahnya sesuai data permintaan dengan sekali aksi.

o Sistem menyediakan fasilitas bagi unit eselon I untuk mengisi/mengubah data droping masingmasing satker di bawahnya satu per satu.

- Pengelolaan laporan oleh satker

o Satker dapat mengisi data laporan hanya pada periode pembayaran yang sedang berjalan dan setelah unit eselon I mengisi data droping.

o Satker dapat mengubah realisasi pembayaran berdasarkan rincian kebutuhan yang telah diisi pada saat permintaan.

o Satker dapat menambah/mengubah/menghapus rincian penyetoran pajak dan saldo akhir.

o Jumlah tunjangan kinerja yang dibayar ke pegawai ditambah jumlah setoran tidak boleh melebihi dana yang tersedia (saldo awal ditambah droping).

o Saldo akhir otomatis berubah setiap kali satker mengisi realisasi pembayaran tunjangan kinerja dan setoran.

o Setelah selesai mengisi data realisasi pembayaran tunjangan kinerja dan setoran, satker dapat 
mengirimkan laporan

o Satker tidak dapat mengubah data setelah mengirimkan laporan.

C. Perancangan UML

1. Use Case Diagram

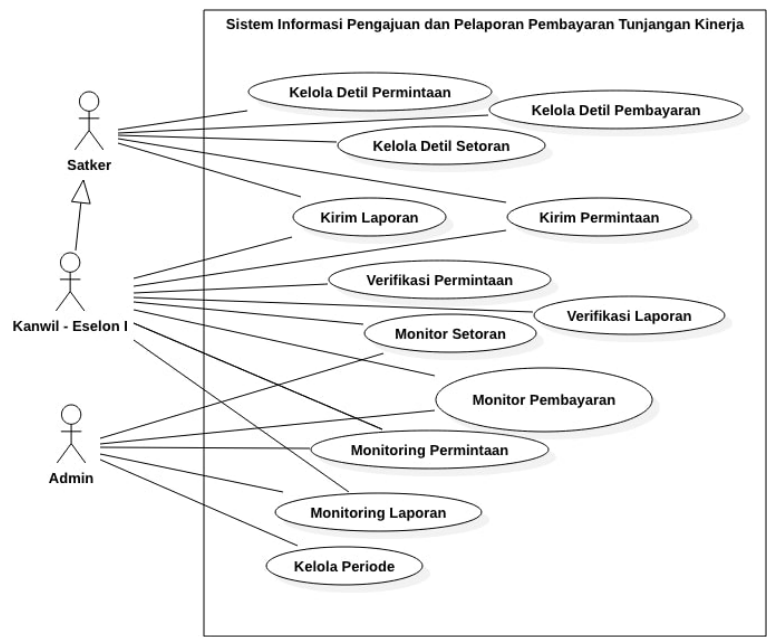

Gambar 3. Use Case Diagram Sistem Informasi Pengajuan dan Pelaporan Tunjangan Kinerja Kementerian Keuangan

\section{Activity Diagram}

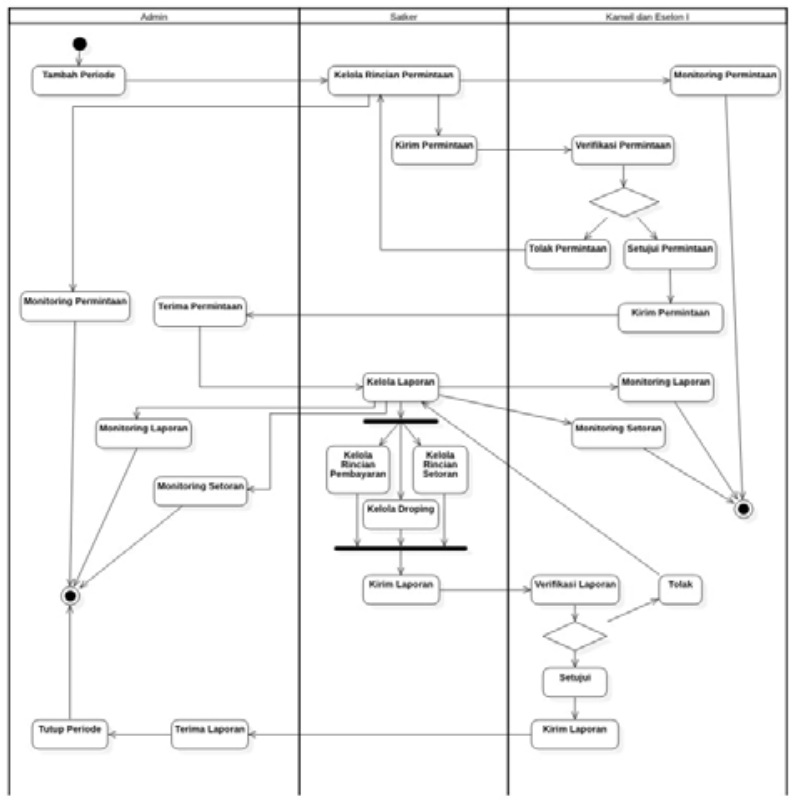

Gambar 4. Activity Diagram Sistem Informasi Pengajuan dan Pelaporan Tunjangan Kinerja Kementerian Keuangan
3. Sequence Diagran

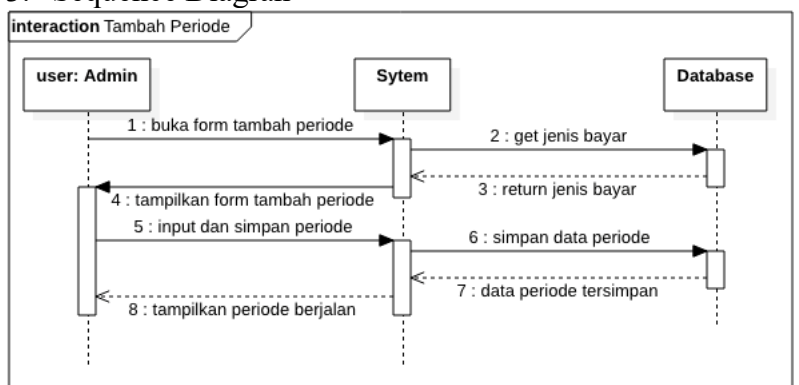

Gambar 5. Sequence Diagram Tambah Periode

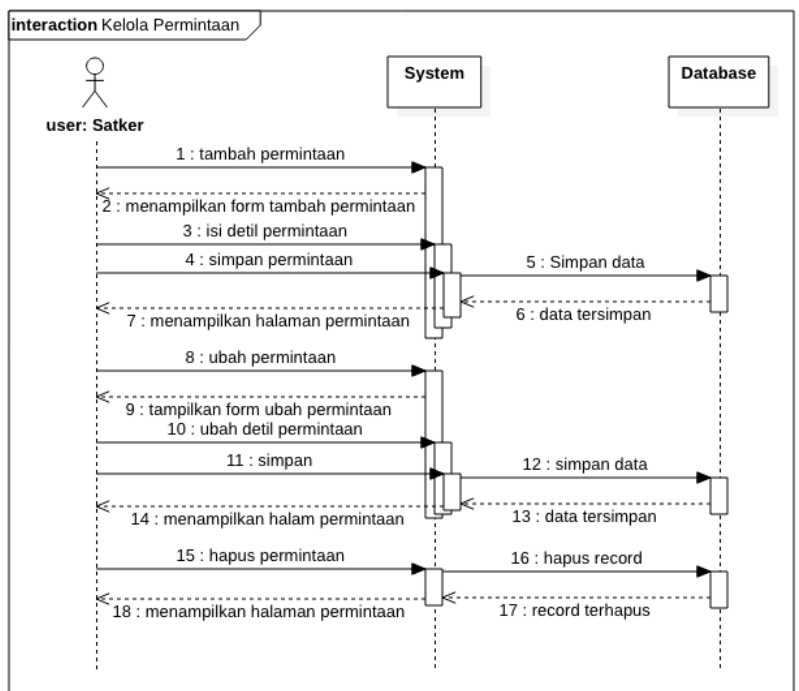

Gambar 6. Sequence Diagram Kelola Permintaan

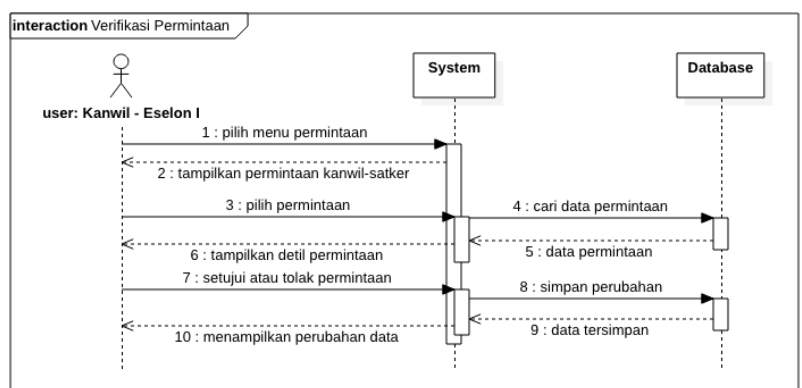

Gambar 7. Sequence Diagram Verifikasi Permintaan

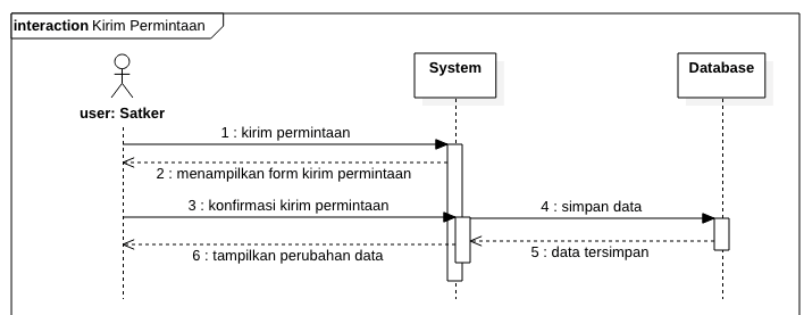

Gambar 8. Sequence Diagram Kirim Permintaan

ISSN : :2301-7988

E-ISSN : 2581-0588

DOI : $10.32736 /$ sisfokom.v8i2.641 
4. Class Diagram

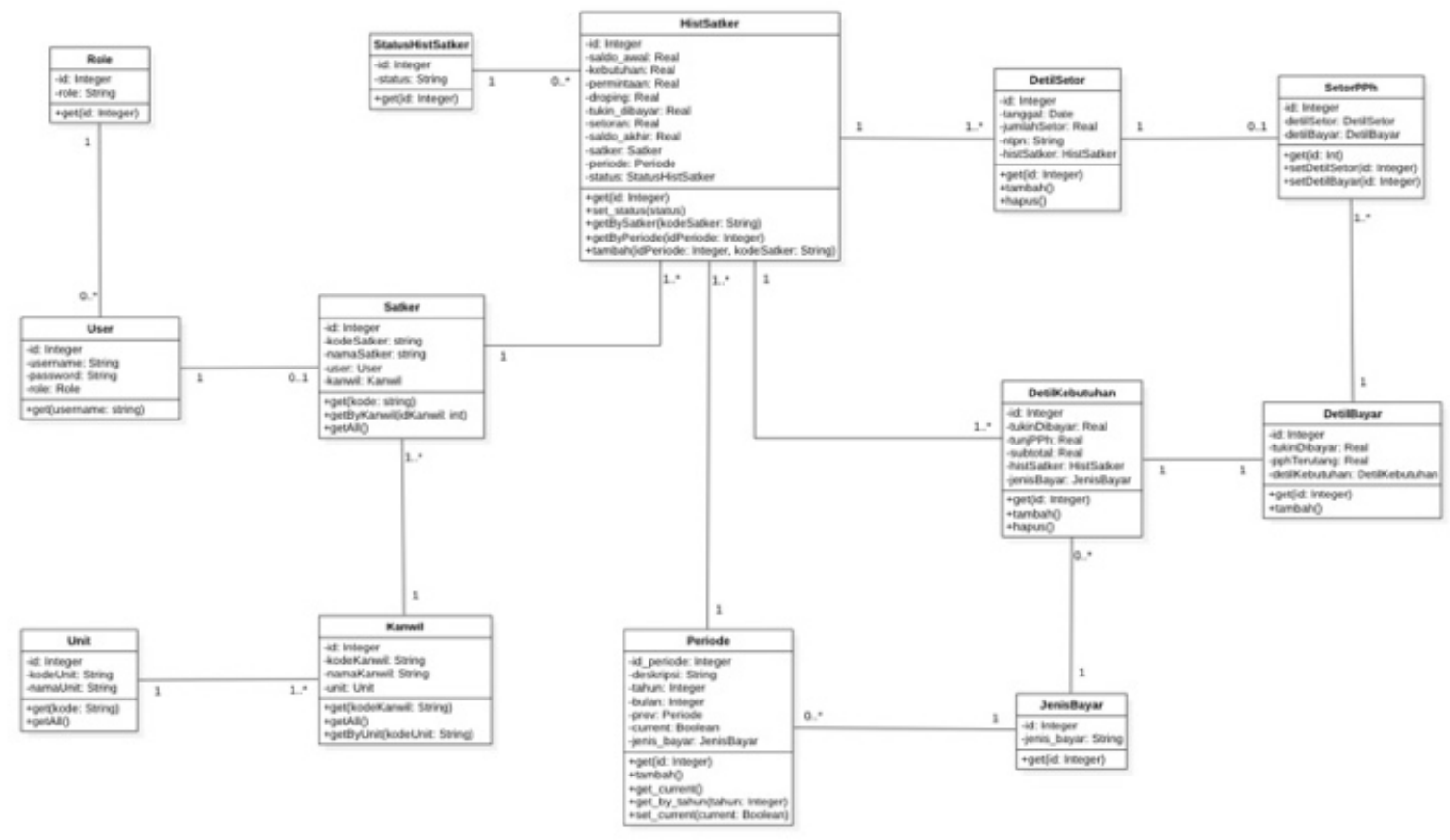

Gambar 9. Class Diagram

D. Perancangan Basis Data

1. ERD

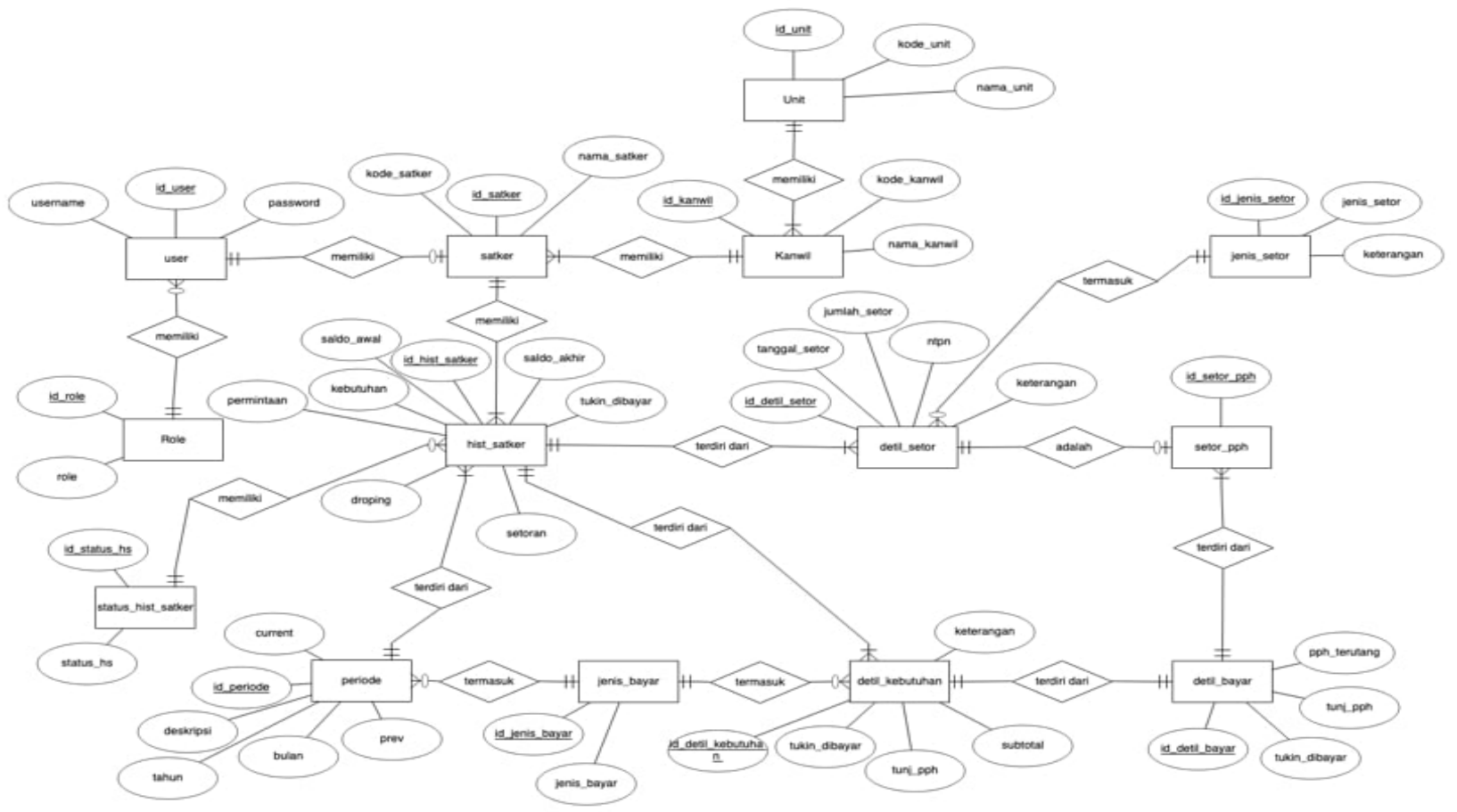

Gambar 10. Entity Relationship Diagram

ISSN $\quad: 2301-7988$

E-ISSN : 2581-0588

DOI $\quad: 10.32736 /$ sisfokom.v8i2.641 
Jurnal SISFOKOM, Volume 08, Nomor 02, September 2019

E. Perancangan Antar Muka

1. Halaman Utama

Halaman utama akan menampilkan histori periode pembayaran ketika tidak ada periode yang sedang berjalan.

\begin{tabular}{|l|}
\hline Periode Pembayaran Saat ini \\
\hline Tidak ada periode pembayaran saat ini \\
Tambah Periode \\
\hline
\end{tabular}

\begin{tabular}{|ll|}
\hline Histori Periode Pembayaran & + \\
\hline \hline
\end{tabular}

Gambar 11. Halaman Utama Ketika Tidak Ada Periode Berjalan

Atau akan menampilkan detil periode yang sedang berjalan.

\section{Periode Pembayaran Saat Ini}

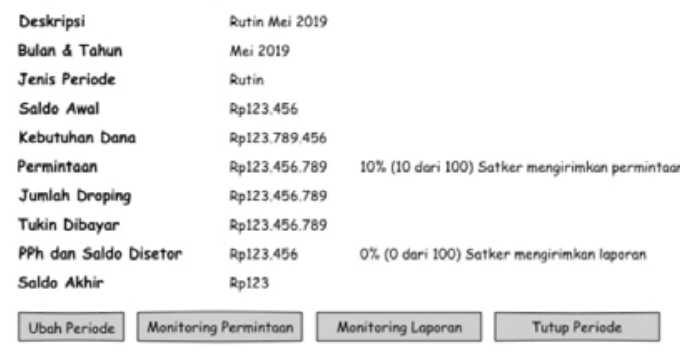

Gambar 12. Halaman Utama Ketika Ada Periode Berjalan

2. Halaman Monitoring

Monitoring Permintaan Tunjangan Kinerja Rutin April 2019

\begin{tabular}{|c|c|c|c|c|c|c|}
\hline No & Unit Eselon I & Soldo Anal & Kebutuhan & Permintion & Progress & Actions \\
\hline 1 & Ditjen MaA & Rp:123 & $R_{p} 123$ & Rp123 & $13 \%(5 / 45)$ & What detill \\
\hline 2 & Ditijen $8 B 8$ & Rp:123 & $R_{p} 123$ & Rp:123 & $13 \%(5 / 45)$ & Lhat detil \\
\hline 3 & Ditjen cce & Rp123 & $R_{p} 123$ & Rp123 & $13 \%(5 / 45)$ & Lhat detil \\
\hline
\end{tabular}

Gambar 13. Halaman Monitoring Tingkat Kementerian

\begin{tabular}{|c|c|c|c|c|c|c|}
\hline Mo & torir & aan & $\begin{array}{l}\text { njanga } \\
\text { tjen } A\end{array}$ & Kinerj & Rutin & il 2019 \\
\hline No & Konnal & Soldo Amal & Kebutuhen & Permintion & Progress & Actions \\
\hline 1 & Kanali $A B C$ & epp123 & Ap 123 & Appt23 & $13 \times(5 / 45)$ & Lhat detil \\
\hline 2 & Komal RST & Apl23 & $A_{p} 123$ & Apt23 & $13 \%(5 / 45)$ & Lhet detil \\
\hline 3 & Konanil XYZZ & Apl23 & Ap 123 & Appt23 & $13 \times(5 / 45)$ & that detil \\
\hline
\end{tabular}

Gambar 14. Halaman Monitoring Tingkat Unit Eselon I

\begin{tabular}{|c|c|c|c|c|c|c|}
\hline \multicolumn{7}{|c|}{ Kanwil $A B C$} \\
\hline No & Sother & Soldo Amel & Kebutuhen & Permintoon & Progress & Actions \\
\hline 1 & Sather Dummy I & Rp123 & $\operatorname{Rp} 123$ & $R p 123$ & $13 \%(5 / 45)$ & Lihat detili \\
\hline 2 & Sather Dummy II & Rp123 & Rp 123 & Rp:123 & $13 \%(5 / 45)$ & Lithat deta: \\
\hline 3 & Sother Dummy III & App123 & Ap 123 & Apl23 & $13 \%(5 / 45)$ & Lihat detil \\
\hline
\end{tabular}

Gambar 15. Halaman Monitoring Tingkat Kanwil

3. Halaman Detil Permintaan Satker

Permintaan Tunjangan Kinerja Rutin April 2019 Satker Dummy I

$\begin{array}{ll}\text { Selde Awal } & \text { Rp123.456 } \\ \text { Kebutuhan Dana } & \text { Rp123.789.456 } \\ \text { Permintoan } & \text { Rp123.456.789 }\end{array}$

Detil Kebutuhan

Tambah Kebutuhan

\begin{tabular}{|c|c|c|c|c|c|c|}
\hline No & Keterangan & $\begin{array}{l}\text { Jenis } \\
\text { Pembogaren }\end{array}$ & Tukin Dibayor & Tunj. PPh & Jumlah & \\
\hline 1 & Tukin Rutin & Rutin & Rpp123 & $R_{P} 123$ & Rp 123 & Ubah \\
\hline \multirow[t]{2}{*}{2} & Rapel Kenoiken Grode & Ropel & Rp123 & $R_{p} 123$ & Rp123 & Ubah \\
\hline & Total & & Rpl23 & $R_{Q} 123$ & Rp123 & \\
\hline
\end{tabular}

Gambar 16. Halaman Permintaan Satker

4. Halaman Detil Laporan Satker

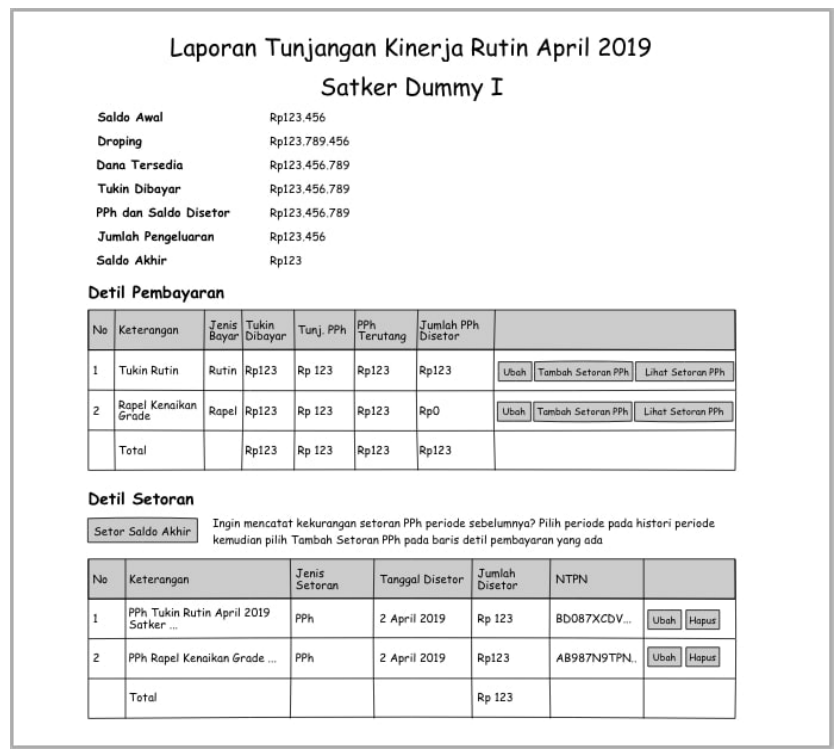

Gambar 17. Halaman Laporan Satker

5. Rancangan Masukan Periode

ISSN $\quad: 2301-7988$

E-ISSN : 2581-0588

DOI $\quad: 10.32736 /$ sisfokom.v8i2.641 


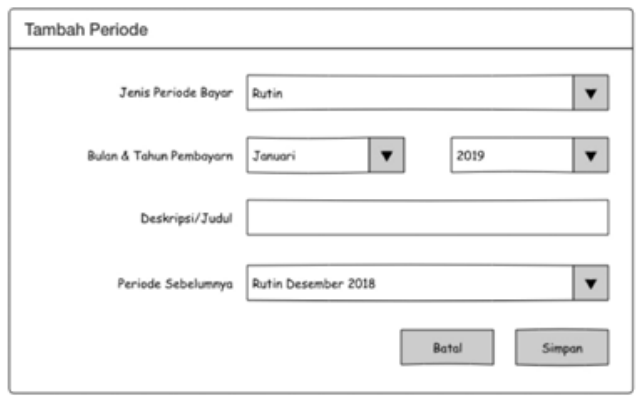

Gambar 18. Rancangan Masukan Periode

6. Rancangan Masukan Rincian Kebutuhan

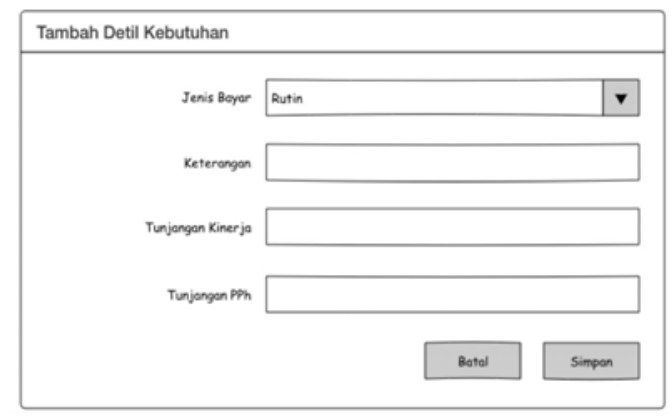

Gambar 19. Rancangan Masukan Rincian Kebutuhan

7. Rancangan Masukan Detil Bayar

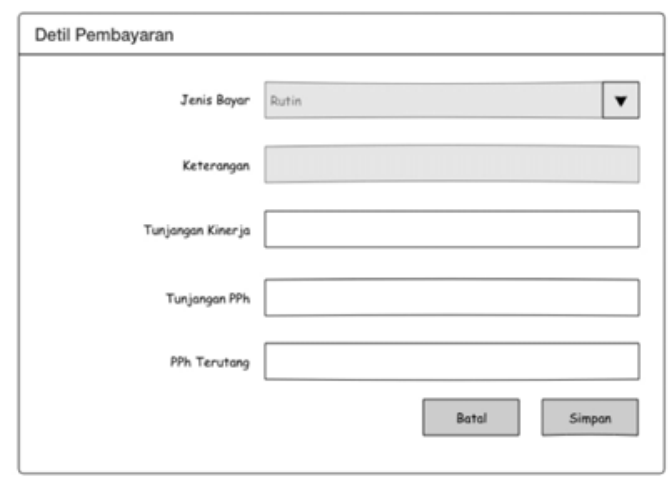

Gambar 20. Rancangan Masukan Detil Bayar

8. Rancangan Masukan Setoran

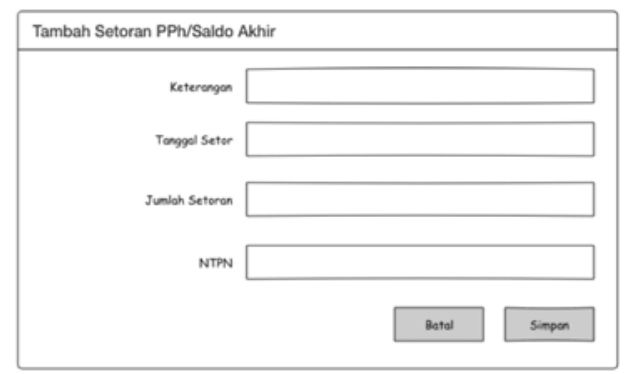

Gambar 21. Rancangan Masukan Detil Setor

9. Rancangan Masukan Droping

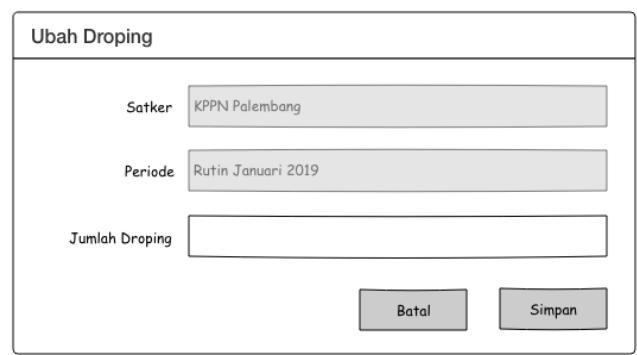

Gambar 22. Rancangan Masukan Droping

\section{F. Evaluasi Hasil Perancangan}

Evaluasi adalah proses penentuan usability dan acceptability dari produk atau desain [12]. Usability adalah derajat kemampuan sebuah perangkat lunak untuk membantu penggunanya dalam menyelesaikan sebuah tugas [13]. Sepuluh prinsip [12] yang digunakan dalam evaluasi rancangan sistem informasi pengajuan dan pelaporan pembayaran tunjangan kinerja Kementerian Keuangan adalah:

- Visibilitas dari status sistem

Prinsip ini berkaitan dengan pertanyaan seperti : "Dimana saya sekarang?" dan "Dimana jalan selanjutnya?". Tampilan menu prototipe sistem informasi pengajuan dan pelaporan pembayaran tunjangan kinerja Kementerian Keuangan dibuat sederhana dan ada penanda menu yang aktif. Halaman yang pertama kali dimuat setelah login adalah menu periode pembayaran. Terdapat informasi apakah saat ini terdapat periode pembayaran berjalan, jika ada akan ditampilkan dan jika tidak ada akan ada informasi yang mudah dibaca dan dimengerti serta tombol yang cukup mencolok untuk menambah periode. Sehingga pengguna, dalam hal ini Biro Perencanaan dan Keuangan akan langsung paham apa yang harus dilakukan.

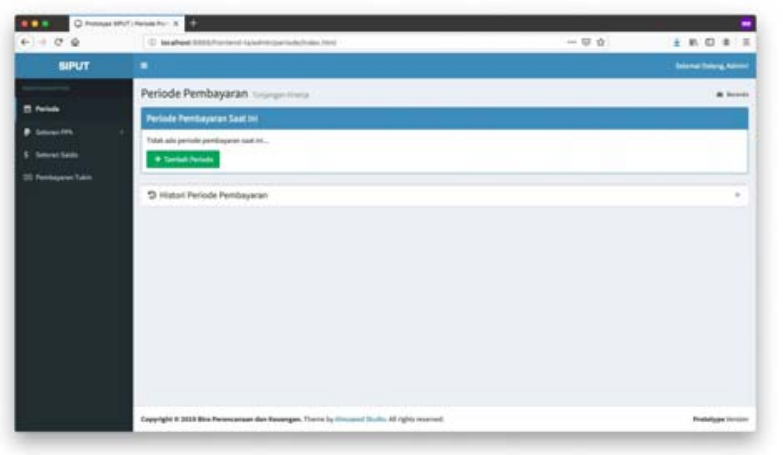

Gambar 23. Prototype Halaman Utama Admin Ketika Tidak Ada Periode Berjalan

- Kesesuaian antara sistem dengan dunia nyata

Tampilan prototipe sistem informasi pengajuan dan pelaporan pembayaran tunjangan kinerja Kementerian Keuangan menggunakan bahasa dan istilah yang umum digunakan oleh pengguna dalam bidang pengelolaan tunjangan kinerja. Dari hasil evaluasi dengan pegawai Biro 
Perencanaan dan Keuangan, pengguna tidak mengalami kesulitan dalam memahami bahasa dan istilah yang digunakan karena cukup familiar dengan bidang pekerjaannya.

- Kendali dan kebebasan pengguna

Kendali dan kebebasan pengguna berkaitan dengan ketidaksengajaan pengguna memilih tautan menu yang tidak diinginkan. Maka dibutuhkan sebuah "pintu darurat" bagi pengguna untuk keluar dari kondisi tersebut. Prototipe sistem informasi pengajuan dan pelaporan pembayaran tunjangan kinerja Kementerian Keuangan menyediakan menu yang mudah diakses di bagian kiri setiap halaman.

- Standar dan konsistensi

Untuk mencapai standar dan konsistensi antar muka, digunakan template AdminLTE sehingga setiap halaman memiliki desain, warna, dan tema yang sama.

- Pencegahan kesalahan

Rancangan prototipe sistem informasi pengajuan dan pelaporan pembayaran tunjangan kinerja Kementerian Keuangan telah memperhatikan tipe inputan pada setiap masukan. Hal ini akan mempermudah ketika rancangan diimplementasikan dalam pengkodean aplikasi.

- Bantu pengguna untuk mengenali, mendiagnosa, dan mengatasi masalah

Prinsip ini dikenal dengan recognition rather than recall (memory), yaitu pengguna tidak seharusnya mengingat informasi setiap bagian sistem. Hasil evaluasi dengan pegawai Biro Perencaanan dan Keuangan, pengguna cukup mudah mengenali menu navigasi maupun tombol-tombol yang tersedia guna menyelesaikan tugasnya. Contohnya pada halaman periode berjalan, terdapat tombol-tombol di bagian bawah sehingga pengguna tidak perlu mencari-cari dimana menu/tombolnya ketika akan melakukan sesuatu (misal memonitor permintaan atau mengubah deskripsi periode).

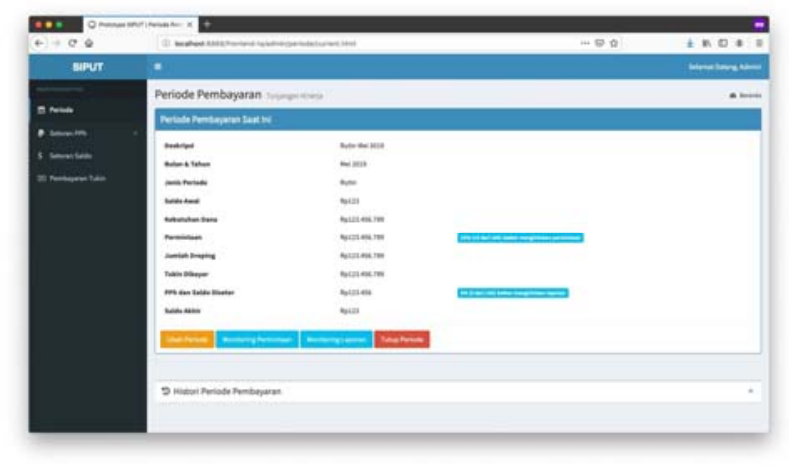

Gambar 24. Prototype Halaman Periode Berjalan

- Fleksibilitas dan efisiensi

Pada halaman periode pembayaran terdapat bagian "Histori Periode Pembayaran" yang dapat di-expand jika diperlukan. Hal ini memberikan fleksibilitas bagi pengguna untuk melihat informasi periode pembayaran dengan efisien tanpa harus berpindah halaman.

- Estetika dan desain yang minimalis

Desain yang minimalis adalah strategi untuk menampilkan hanya konten yang diperlukan untuk mendukung tujuan/fungsi utama dari sebuah sistem. Rancangan sistem informasi pengajuan dan pelaporan pembayaran tunjangan kinerja Kementerian Keuangan menggunakan menu yang sederhana dan tidak rumit. Halaman awal yang tampil ketika login juga tidak bertele-tele, namun langsung mengkondisikan pengguna utuk memulai tugas utamanya.

- Pertolongan pengguna mengenal, berdialog dan memperbaiki kesalahan

Rancangan sistem informasi pengajuan dan pelaporan pembayaran tunjangan kinerja Kementerian Keuangan menyediakan fasilitas bagi pengguna untuk memperbaiki kesalahan melalui fitur ubah data, misalnya mengubah informasi periode bayar oleh Biro Perencanaan dan Keuangan, atau mengubah data detil permintaan, detil bayar, dan detil setoran oleh satker.

- Fitur bantuan dan dokumentasi

Fitur bantuan dan dokumentasi belum dimasukkan dalam rancangan. Meskipun fitur ini cukup membantu pengguna, namun berdasarkan hasil diskusi dengan pegawai Biro Perencanaan dan Keuangan fitur ini tidak menjadi prioritas utama dengan pertimbangan:

o Pengguna aplikasi adalah pegawai yang sehari-hari bertugas mengelola keuangan (termasuk tunjangan kinerja) yang biasanya akan cepat beradaptasi dengan aplikasi baru yang terkait dengan bidang tugasnya.

o Jika terdapat penggantian petugas (mutasi), biasanya pegawai lama akan melatih pegawai baru sebelum berpindah ke tempat tugas baru. Pegawai baru biasanya berasal dari lulusan sekolah kedinasan yang sudah familiar dengan pengelolaan keuangan instansi pemerintah sehingga cepat beradaptasi.

o Aplikasi baru biasanya hanya memerlukan panduan ringkas yang disebar melalui grup media sosial WhatsApp.

\section{PENUTUP}

\section{A. Kesimpulan}

Prototipe sistem informasi pengajuan dan pelaporan pembayaran tunjangan kinerja Kementerian Keuangan yang telah dirancang secara umum telah memenuhi kebutuhan pengguna, yaitu:

- Prototipe sistem telah dirancang untuk dapat mencatat pengajuan pembayaran (permintaan dana) dan pelaporan tunjangan kinerja yang dilakukan oleh satker, sehingga pengguna dapat dengan mudah melihat kembali catatan tersebut.

- Hasil perancangan telah menyediakan fitur monitoring permintaan dan pelaporan tunjangan kinerja. Biro Perencanaan dan Keuangan dapat melihat progres permintaan dan pelaporan per unit eselon I, per kanwil maupun per satker.

- Hasil perancangan telah menyediakan fitur bagi Biro Perencanaan dan Keuangan untuk dapat melihat informasi penyetoran pajak secara terperinci. 


\section{B. Saran}

Meskipun demikian diperlukan penelitian lanjutan agar manfaat protoype sistem ini dapat dioptimalkan, diantaranya:

- Implementasi sistem informasi pengajuan dan pelaporan pembayaran tunjangan kinerja Kementerian Keuangan sehingga aplikasi dapat digunakan secara riil.

- Memperluas ruang lingkup penelitian pada tingkat satker, kanwil dan unit eselon I sehingga kebutuhan pengguna (user requirement) pada tingkat tersebut dapat diidentifikasi dengan lebih komprehensif.

- Mengintegrasikan sistem informasi pengajuan dan pelaporan tunjangan kinerja dengan sistem pembayaran tunjangan kinerja yang sudah ada sehingga catatan pembayaran tunjangan kinerja per pegawai dapat dilihat dalam satu sistem aplikasi.

\section{REFERENSI}

[1] A. Rohman, "Tahap Awal Usulan Integrasi Sistem Pengadan Secara Elektronik ( SPSE ) Berbasis Sistem Informasi Geografis ( SIG ) dalam Pengadaan Barang / Jasa Pemerintah Bidang Konstruksi contoh kasus : Konstruksi Jalan Raya,” Indones. J. Geospatial, vol. 4, no. 1, hal. 4653, 2015.

[2] A. Nugroho dan N. Septafianti, "Aplikasi Monitoring Pengadaan Barang/Jasa Pada Direktorat Penilaian Keamanan Pangan Badan POM RI," J. Format, vol. 6, no. 2, hal. 39-55, 2016

[3] A. S. Putra dan O. M. Febriani, "SISTEM INFORMASI MONITORING INVENTORI BARANG PADA BALAI RISET STANDARDISASI INDUSTRI BANDAR LAMPUNG," J. Inform., vol. 13, no. 1, hal. 90-98, 2013.
[4] M. Tajuddin dan A. Manan, "Rancang Bangun Sistem Informasi Monitoring Satuan Kerja Dalam Rangka Good Governance," J. Matrik, vol. 15 , no. 1, hal. $35,2017$.

[5] W. Andriani, "Pengaruh Kapasitas Sumber Daya Manusia dan Pemanfaatan Teknologi Informasi Terhadap Keterandalan dan Ketepatwaktuan Laporan Keuangan Pemerintah Daerah (Studi pada Pemerintah Daerah Kab . Pesisir Selatan)," J. Akunt. Manaj., vol. 5, no. 1, hal. 69-80, 2010 .

[6] I. Sommerville, Software Engineering, 10th ed. Pearson, 2016.

[7] D. Purnomo, "Model Prototyping Pada Pengembangan Sistem Informasi," J. Inform. Merdeka Pasuruan, vol. 2, no. 2, hal. 54-61, 2017.

[8] H. Noprisson dan Budiyarti, "Aplikasi Manajemen Pemeliharan Produk Perangkat Lunak," J. Sci. Appl. Informatics, vol. 1, hal. 1-6, 2018.

[9] Kementerian Keuangan, Peraturan Menteri Keuangan Nomor 273/PMK.01/2014 tentang Pelaksanaan Pembayaran Tunjangan Kinerja Pegawai di Lingkungan Kementerian Keuangan. Indonesia, 2014.

[10] S. Easterbrook, "the PIECES Framework." [Daring]. Tersedia pada: http://www.cs.toronto.edu/ sme/CSC340F/readings/PIECES.html. [Diakses: 09-Mei-2019].

[11] S. Ramadhani dan W. A. Kusuma, "PIECES Framework untuk Analisa Tingkat Kepuasan Pengguna dan Kepentingan Sistem Informasi," J. Tenologi Manaj. Inform., vol. 4, no. 2, 2018

[12] P. Savitri dan M. Ispani, "Review Desain Interface Aplikasi Sopppos Menggunakan Evaluasi Heuristik," Simetris J. Tek. Mesin, Elektro dan Ilmu Komput., vol. 6, no. 1, hal. 95, 2017.

[13] A. Ali, E. Pramana, dan S. Tjandra, "Evaluasi Heuristik Pada Web Based Learning Untuk Meningkatkan Aspek Usability Sistem," J. Insa. Comtech, vol. 1, no. 1, hal. 17-25, 2016 